\title{
Strupczewski Method for Parametric Design Hydrographs in Ungauged Cross-Sections
}

\author{
Wiesław Gądek ${ }^{1}$, Beata Baziak $^{2}$, Tamara Tokarczyk ${ }^{3}$ \\ ${ }^{1}$ Institute of Water Engineering and Water Management, Cracow University of Technology, \\ ul. Warszawska 24, 31-155 Kraków, e-mail: wieslaw.gadek@iigw.pk.edu.pl \\ ${ }^{2}$ Institute of Water Engineering and Water Management, Cracow University of Technology, \\ ul. Warszawska 24, 31-155 Kraków, e-mail: beata.baziak@iigw.pk.edu.pl \\ ${ }^{3}$ Institute of Meteorology and Water Management PIB -Wrocław Branch, Drought and Flood Modelling \\ Center in Wrocław, ul. Parkowa 30, 51-616 Wrocław, e-mail: tamara.tokarczyk@imgw.pl
}

(Received April 04, 2017; revised June 30, 2017)

\begin{abstract}
Nonparametric hydrographs, constructed by the method suggested by Archer, are usually used for developing parametric design hydrographs. Flow changes in time are described by the UPO ERR Gamma complex function, which denotes a Gamma curve reformulated to have a Unit Peak at the Origin (abbreviated to UPO), supplemented by the Exponential Replacement Recession (ERR) curve. It may be observed, that this solution does not work in some areas of the upper Vistula and middle Odra catchments when the times of the rising limb of a hydrograph are higher than the times of the falling limb, i.e. when the skewness coefficient approximates 0.5 or higher values. Better results can be achieved with the function suggested by Strupczewski in 1964. It is a solution which uses two parameters of the flood hydrograph.

The objective of the present paper is to assess the Strupczewski method by comparing it with a complex UPO ERR Gamma function for gauged cross-sections in the upper Vistula and middle Odra catchments. The assessment was carried out for 30 gauged cross-sections (15 in each river catchment). The parameters were optimized for width-hydrograph descriptors W75 and W50, designed by the Archer method, and for the skewness coefficient $s$. Optimization using only two width-hydrograph descriptors aims to test how the Strupczewski method works for cross-sections for which the values of width-hydrograph descriptors W75 and W50 are known. The assessment of both methods was carried out with reference to a nonparametric hydrograph constructed by the Archer method. The results of these assessments suggest that the Strupczewski method may be used not only for gauged cross-sections, but also for ungauged ones.
\end{abstract}

Key words: nonparametric design hydrograph, Archer method, parametric design hydrograph, flow descriptor, Strupczewski method, UPO ERR Gamma curve

\section{Introduction}

The authors of the paper define the term "design hydrograph" as a flow hydrograph presenting a typical course of a flood hydrograph for a specific place, which is used for 
design purposes. Such a flood hydrograph represents the response of the catchment to heavy precipitation. It is described analytically by various functions and determined parameters of these functions.

Parametric design hydrographs find increasingly more applications in designing hydraulic structures and in different computational procedures dealing with water management in which flow variability plays a crucial role in the design or computational process. The data describing the course, volume, rising time and duration time of a flood provide a basis for determining the time of water remaining in the inter-embankment zone, for calculating the water volume overspilling the embankment crown or the volume of water discharged as a result of an embankment break, as well as for solving numerous other problems of hydraulic structures and water management. The knowledge of wave transformation in the watercourse channel is crucial for designing structures in urbanized catchments, where storm sewer systems and impervious surfaces play a key role (WMO 2008, Zevenbergen et al 2011). The impact of urbanized areas (existing and planned development) on flood hazard is increasingly assessed. For the remaining catchments, hydrographs can be used to design of retention reservoirs, one of which task is to mitigate the effects of flood and drought (Mioduszewski 2012, Mioduszewski 2014, Tokarczyk, Szalińska 2013), as well as in developing guidelines for reservoir control.

Hydrological models are used to address issues connected with a broadly defined flood hazard (Apel et al 2006, Vrijling et al 1998, Criss, Winston 2008, Hattermann, Kundzewicz 2010, Krišèiukaitiene et al 2015, Wałęga 2013, Pietrusiewicz et al 2014, Ozga-Zielińska et al 2002). A hydrograph is a result of model application and an assumed hyetograph. The assumed hyetograph not always corresponds to the real flood formation, as has been demonstrated by computational simulations (Gądek, Bodziony 2015). It may be noticed, that due to the homogeneity of the solution, parametric design hydrographs supplemented with a base flow and a groundwater flow are increasingly often used instead of hydrological modelling.

Parametric hydrographs require that their course be a functional description of nonparameteric hydrographs. The methods used in Poland to determine nonparametric hydrographs are the Warsaw University of Technology method (Gądek, Srodula 2014) and the Cracow method (Gądek, Tokarczyk 2015), in which hydrographs are determined by flow for a given time, and the Archer method using time averaging (Archer et al 2000). The Warsaw University of Technology method and the Cracow method may be, after some modifications, adjusted to the rules of Archer's nonparametric hydrograph description (Gądek et al 2017). The following methods are used to determine parametric hydrographs: McEnroe (1992), Baptista, Michel (1990), and parabolic functions using Gama distribution, Inverse Gaussian distribution, the Negative Binomial curve (O'Connor et al 2014), the Weibull distribution and Hayashi curve (Hayashi et al 1986) and the Strupczewski method (Strupczewski 1964, Gądek et al 2016). 
The objective of this study was to determine whether the analytical method of hydrographic description proposed by Strupczewski can be used to describe parametric design hydrographs in uncontrolled cross-sections. This goal was achieved by comparing parametric design hydrographs obtained by the Strupczewski method with the UPO ERR Gamma hydrographs, which denotes Gamma curves reformulated to have a Unit Peak at the Origin (UPO) supplemented by the Exponential Replacement Recession curve (ERR) (O'Connor et al 2014). It was assumed that the optimization parameters for both methods would be based on width-hydrograph descriptors W75 and W50 (hydrograph width [hours] at 75\% and 50\% of peak flow) and the skewness coefficient $s$ determined for the width-hydrograph descriptor W50. The results were evaluated with reference to a whole nonparametric hydrograph developed by the Archer method. The values of descriptors were found from a nonparametric hydrograph for the 4 biggest registered flood waves in a given gauged cross-section.

\section{Brief Description of the Archer Parametric Method}

Archer (Archer et al 2000) developed a method of constructing nonparametric hydrographs, which belongs to a group of issues referred as "designed hydrology". Fig. 1 presents a hydrograph constructed by this method on the basis of the four biggest registered flood waves.

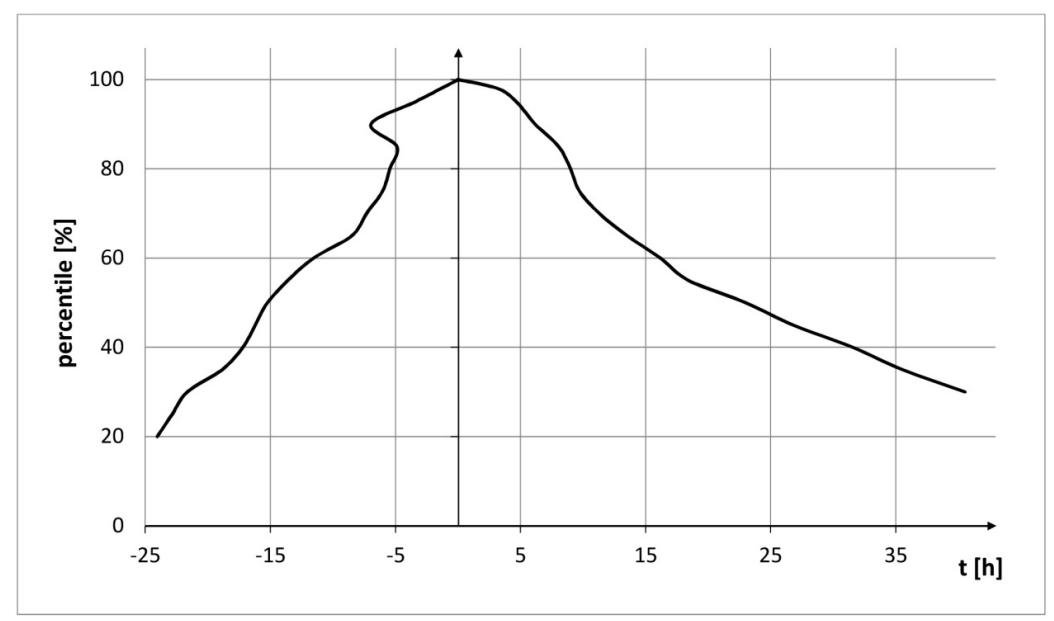

Fig. 1. Nonparametric design hydrograph developed according to the Archer method. Source: the authors' own results

Archer's nonparametric hydrograph is presented in a semi-standardized approach, in which the flow is shown as a percentile within a range from 0 to $100 \%$ on the vertical axis, while the duration of individual percentile values is plotted on the horizontal axis. The hydrograph has an independent rising limb and a falling limb. For the rising limb of the hydrograph, it is assumed that time has negative values. For the falling 
limb, the time has positive values and is counted from the maximum value (maximum percentile value $100 \%$ at $t=0$ ). Individual percentile values constitute the medium values (median) of flows from the rising limb of input hydrographs and from the falling limb (O'Connor et al 2014).

It was assumed that the nonparametric hydrograph would be constructed on the basis of the four largest flood waves. If it was impossible to determine the value of percentile $50 \%$ on both limbs (rising and falling), the wave was replaced by the next one from the interval series of the largest flood waves. The rising limb of the flood hydrograph used to construct the nonparametric design hydrograph uses only the part of the hydrograph with non-descending flows, occurring from a given flow value to the peak flow. Values of percentiles for the receding limb are determined according to similar principles, but in this case non-ascending flows are taken into consideration.

\section{Brief Description of the Strupczewski Method}

The Strupczewski method was developed in two independent versions (Strupczewski 1964, Ciepielowski 1987, 2001). The first solution refers to hydrographs that occur in catchments the most frequently and the other to hydrographs with a prolonged time of falling in relation to average hydrographs. Both equations use Pearson density distributions, but type III was used in the first equation and type IV in the second one. The first equation, after an adjustment to the input nonparametric hydrograph according to Archer, has the following form:

$$
q_{t}=\left(\frac{t}{t_{w}}+1\right)^{m} \exp \left\{\left[\frac{m}{n}\left(\frac{t}{t_{w}}\right)^{n}\right]\right\} 100 \%
$$

where:

$q_{t} \quad-$ the percentile of flow at the time $t$ counted from the beginning of flood, \%,

$t_{w} \quad-\quad$ the rising time, $h$,

$t \quad-$ time counted from the assumed beginning of flood, $h$,

$m, n$ - parameters of the flood shape.

The flood shape parameters $m$ and $n$ are determined from functions $f_{0}$ and $f_{1}$ suggested by the author:

$$
\begin{gathered}
f_{0}(m, n)=\frac{n^{\left(\frac{m+1}{n}-1\right)}}{m^{\left(\frac{m+1}{n}\right)}} e^{m / n} \Gamma\left(\frac{m+1}{n}\right), \\
f_{1}(m, n)=\left(\frac{n}{m}\right)^{1 / n} \frac{\Gamma\left(\frac{m+2}{n}\right)}{\Gamma\left(\frac{m+1}{n}\right)},
\end{gathered}
$$

where:

$\Gamma$ - function of the Gamma distribution, which was not used in this study. 


\section{Brief Description of the UPO ERR Gamma Method}

The UPO ERR Gamma complex function originates from analyses which revealed that the Gamma function insufficiently describes the shape of a nonparametric hydrograph constructed by the Archer method. The Gamma curve was modified in the falling limb by application of exponential replacement recession (O'Connor et al 2014) from the inflection point at the hydrograph top. In this method, the Gamma function assumes the following form:

$$
q_{t}=\left(1+\frac{t}{t_{w}}\right)^{n-1} \exp \left[\frac{-t}{t_{w}}(n-1)\right] 100 \%
$$

where:

$n$ - a parameter of the hydrograph shape.

The inflection point coordinates are determined from the following dependence:

$$
\begin{gathered}
t_{I}=\frac{t_{w}}{\sqrt{n-1}}, \quad \text { where } n>1, \\
q_{I}=\left(1+\frac{1}{\sqrt{n-1}}\right)^{n-1} \exp (-\sqrt{n-1}) 100 \%,
\end{gathered}
$$

where:

$t_{1}$ - time at which the inflection point occurs, $t$,

$q_{I}-$ the percentile of flow for the time of occurrence $t_{I}, \%$.

The Exponential Replacement Recession curve is defined by the following equation:

$$
q_{t}=q_{1} \exp \left(-\frac{t-t_{1}}{C}\right) 100 \%
$$

where: $C$ - a parameter of the Exponential Replacement Recession curve.

\section{Characteristics of Selected Catchments}

The results were analyzed on the basis of flow hydrographs observed in 30 gauged cross-sections, located in the upper Vistula and middle Odra catchments. The catchments represent areas where hydrograph characters shape differently. The selection was made so that the catchments would represent mountain and foothill areas, as well as uplands and lowlands. Their brief characteristics are presented in Table 1, where the catchments are listed according to the river basins (the Vistula basin -1 to 15 , and the Odra basin - 16 to 30 ) and according to the catchment area for a given gauging cross-section. 
Table 1. Short characteristics of the catchments selected for calculations; W50 is a descriptor of a nonparametric flow hydrograph determined according to the Archer method, and the skewness coefficient $s$ was computed for the width-hydrograph descriptor W50

\begin{tabular}{|c|c|c|c|c|}
\hline No. & River gauging station & Catchment area $\left(\mathrm{km}^{2}\right)$ & W50 (h) & $\mathrm{s}(-)$ \\
\hline \multicolumn{5}{|c|}{ The Vistula river catchment } \\
\hline 1 & Żabniczanka - Żabnica & 22.8 & 17.5 & 0.40 \\
\hline 2 & Grajcarek - Szczawnica & 73.6 & 30.1 & 0.48 \\
\hline 3 & Wieprzówka - Rudze & 154 & 22.3 & 0.43 \\
\hline 4 & Uszwica - Borzęcin & 265 & 34.2 & 0.42 \\
\hline 5 & Wisła - Skoczów & 296 & 24.6 & 0.39 \\
\hline 6 & Koprzywianka - Koprzywnica & 498 & 33.7 & 0.45 \\
\hline 7 & Raba - Stróża & 644 & 23.8 & 0.50 \\
\hline 8 & Biała-Koszyce Wielkie & 957 & 18.6 & 0.47 \\
\hline 9 & Przemsza - Jeleń & 2006 & 131.7 & 0.40 \\
\hline 10 & Poprad - Stary Sącz & 2071 & 54.8 & 0.51 \\
\hline 11 & Nida - Brzegi & 3359 & 69.2 & 0.30 \\
\hline 12 & San - Przemyśl & 3686 & 58.3 & 0.62 \\
\hline 13 & Dunajec - Żabno & 6735 & 57.2 & 0.58 \\
\hline 14 & San - Rzuchów & 12180 & 94.2 & 0.57 \\
\hline 15 & Wisła-Zawichost & 50732 & 143.8 & 0.29 \\
\hline \multicolumn{5}{|c|}{ The Odra river catchment } \\
\hline 16 & Nysa Kłodzka - Międzylesie & 49.7 & 9.1 & 0.45 \\
\hline 17 & Bystrzyca - Jugowice & 122 & 18.2 & 0.53 \\
\hline 18 & Bóbr - Kamienna Góra & 190 & 22.7 & 0.51 \\
\hline 19 & Czarna Woda-Gniechowice & 251 & 75.3 & 0.39 \\
\hline 20 & Biała Głuchołaska - Głuchołazy & 283 & 15.9 & 0.29 \\
\hline 21 & Piława-Mościsko & 292 & 65.0 & 0.27 \\
\hline 22 & Strzegomka - Łażany & 362 & 57.8 & 0.28 \\
\hline 23 & Bóbr - Wojanów & 535 & 98.4 & 0.19 \\
\hline 24 & Nysa Kłodzka - Kłodzko & 1084 & 15.1 & 0.47 \\
\hline 25 & Bóbr - Dąbrowa Bolesławiecka & 1713 & 78.4 & 0.25 \\
\hline 26 & Bystrzyca - Jarnołtów & 1721 & 77.5 & 0.24 \\
\hline 27 & Nysa Kłodzka - Bardo & 1744 & 26.3 & 0.42 \\
\hline 28 & Bóbr - Szprotawa & 2879 & 38.2 & 0.40 \\
\hline 29 & Bóbr - Żagań & 4255 & 114.8 & 0.25 \\
\hline 30 & Odra-Cigacice & 39900 & 250.4 & 0.37 \\
\hline
\end{tabular}

Source: authors' own study

\section{Methods}

For a comparative study, it was necessary to modify the formula assumed by Strupczewski for a nonparametric hydrograph constructed by the Archer method. The final version of the equation is shown in Eq. (1). 
The optimization of the shape parameters $m$ and $n$ and the rising time $t_{w}$ in Strupczewski's formula was carried out for two width-hydrograph descriptors, W75 and W50, and for the skewness coefficient $s$ established for width-hydrograph descriptor W50, with the assumption that both shape parameters are positive. This assumption results from the fact that the Strupczewski method has to be applied to both gauged and ungauged cross-sections. In the case of ungauged cross-sections, it is more convenient to present the shape parameters $m$ and $n$ as positive values on GIS (Geographic Information System) thematic layers in a spatial layout.

The smallest deviation of values calculated from flow descriptor set values was used as the selection criterion:

$$
S_{S}=(W 75-\hat{a})^{2}+(b+\hat{b})^{2}+(c+\hat{c})^{2}=\min ,
$$

where:

$\hat{a}$ - width-hydrograph descriptor W75 calculated by the Strupczewski method, $\%$,

$b$ - width-hydrograph descriptor W50 for the rising limb, \%,

$\hat{b}$ - width-hydrograph descriptor W50 calculated by the Strupczewski method for the rising limb, \%,

$c$ - width-hydrograph descriptor W50 for the receding limb, \%,

$\hat{c}$ - width-hydrograph descriptor W50 calculated by the Strupczewski method for the receding limb, \%.

The optimization of the shape parameter $n$ and the rising time parameter $t_{w}$ for the Gamma function was conducted following the same principles:

$$
S_{G}=(W 75-\hat{a})^{2}+(b+\hat{b})^{2}=\min ,
$$

where:

$\hat{a}-$ width-hydrograph descriptor W75 calculated by the UPO ERR Gamma formula, \%,

$\hat{b}$ - width-hydrograph descriptor W50 calculated by the UPO ERR Gamma formula for the rising limb, \%.

For the Exponential Replacement Recession curve (ERR), the parameter $C$ is established as

$$
S_{E}=(c+\hat{c})^{2}=\min ,
$$

where: $\hat{c}$ - width-hydrograph descriptor W50 calculated by the UPO ERR Gamma formula for the falling limb, \%.

Computed nonparametric design hydrographs were compared with nonparametric design hydrographs constructed by the Archer method. 
The parameters of both formulas were determined at the assumed resolution: the shape parameters $m$ and $n$ every 0.05 , the rising time every $0.5 \mathrm{~h}$, and the parameter $C$ every 0.5 .

Four methods were used as the assessment criteria: relative error for width-hydrograph descriptors W75 and W50, mean relative error for percentiles $p=98 \%$, $p=95 \%$, and $p=90 \%$ to $p=25 \%$ within three ranges: above percentiles $p=75 \%$, $p=50 \%$ and $p=25 \%$, volumes of hydrographs above percentiles $p=75 \%, p=50 \%$ and $p=25 \%$. In the case of the lack of percentile $p=25 \%$, the calculations were made for percentile $p=30 \%$. Relative error was calculated from the following relationship:

$$
R E_{p}=\frac{\left|W_{p}-\hat{W}_{p}\right|}{W_{p}},
$$

where:

$R E_{p}$ - the relative error of width-hydrograph descriptor W75 or W50,

$W_{p}$ - width-hydrograph descriptor W75 or W50 determined from a nonparametric design hydrograph, $h$,

$\hat{W}_{p} \quad$ - width-hydrograph descriptor W75 or W50 computed by the Strupczewski formula or the UPO ERR Gamma, $h$.

Mean relative error (Elshorbagy et al 2000) for percentiles $p=75 \%, p=50 \%$ and $p=25 \%$ was calculated as follows:

$$
M R E_{p}=\frac{1}{N_{p}} \sum_{i=1}^{N_{p}} R E_{i},
$$

where:

$M R E_{p}-$ mean relative error for percentile $p=75 \%$ or $p=50 \%$ or $p=$ $25 \%$,

$N_{p} \quad-\quad$ number of percentiles above the calculated value, e.g. 7 for percentile $p=75 \%$ or 121 for percentile $p=50 \%$,

$R E_{i} \quad-$ relative error for $p_{1}=98 \%, p_{2}=95 \%, p_{3}=90 \% \ldots p_{15}=30 \%$, $p_{16}=25 \%$,

$i \quad-$ percentile number.

The relative error of a parametric hydrograph volume determined by the UPO ERR Gamma or Strupczewski method was calculated:

$$
\operatorname{Er} V_{p}=\frac{V_{p}-\hat{V}_{p}}{V_{p}},
$$

where: 
$\operatorname{ErV}_{p} \quad$ - the relative error of a parametric hydrograph volume above percentile $p$,

$V_{p} \quad-\quad$ volume of a nonparametric hydrograph above the percentile $p$,

$\hat{V}_{p} \quad-\quad$ volume of a parametric hydrograph determined by the Strupczewski method or the UPO ERR Gamma above percentile $p$.

The fourth method is a non-standard method used to evaluate the dynamics of flow changes in the ascending and descending parts. This was accomplished by determining the center of gravity of the hydrograph in relation to the flow axis. The center of gravity was determined independently for the flow hydrograph above the percentiles $p=25 \%, p=50 \%$ and $p=75 \%$.

$$
r_{0}=\frac{\sum_{i=1}^{N_{p}} A_{i} l_{i}}{\sum_{i=1}^{N_{p}} A_{i}},
$$

where:

$r_{0} \quad-$ the center of gravity of the hydrograph in relation to the flow axis [h],

$N_{p}-$ the number of percentiles above the computed value, e.g. 7 for percentile $p=75 \%, 12$ for percentile $p=50 \%$ or 17 for percentile $p=$ $25 \%$,

$A_{i}$ - the partial area of the hydrograph between successive percentiles [h],

$l_{i} \quad$ - distance between the gravity center of the partial area and the flow axis $[\mathrm{h}]$.

\section{Results}

Values of width-hydrograph descriptors W75 and W50 and the skewness coefficient $s$ for width-hydrograph descriptor W50 are presented in Table 1 together with the catchment area, separately for the upper Vistula and middle Odra catchments. In Fig. 2, examples of parametric design hydrographs calculated by the UPO ERR Gamma and Strupczewski formulas are juxtaposed with nonparametric hydrographs constructed by the Archer method ( 3 per each catchment). The results of both methods show a poor fit in sections close to the top for all hydrographs; a better fit is obtained by the UPO ERR Gamma function than by the Strupczewski function. Fig. 3 shows examples of hydrographs where the skewness coefficient $s \geq 0.5$, which show that the parametric hydrographs determined by the Strupczewski method are well suited to nonparametric hydrographs.

The following tables present the results of analysis. Relative error shown in Table 2 was calculated from the relationship Eq. (11) for percentiles $p=75 \%$ and $p=50 \%$. Table 3 presents mean relative error for percentiles $p=75 \%, p=50 \%$ and $p=25 \%$ 

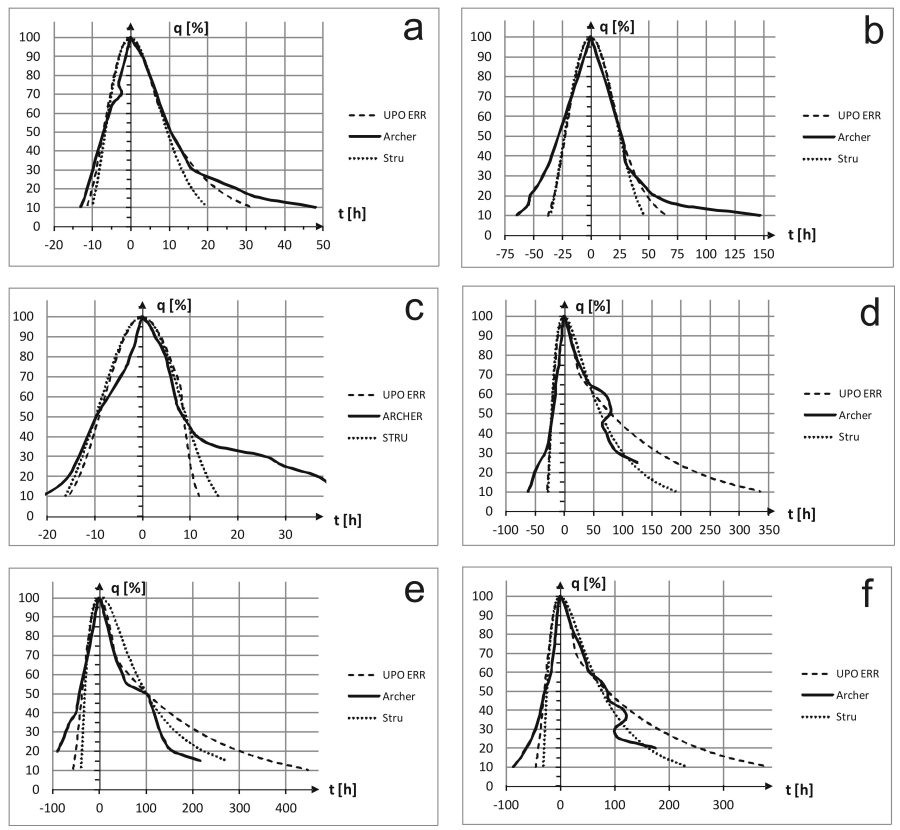

Fig. 2. Parametric design hydrographs determined by the UPO ERR Gamma function (UPO ERR) and the Strupczewski function (Stru) and a nonparametric hydrograph determined by the Archer method (Archer et al 2000) for the 4 largest flood waves in the following cross-sections: a. Żabniczanka - Żabnica, b. Poprad - Stary Sącz, c. Przemsza - Jeleń, d. Bóbr - Szprotawa, e. Wisła - Zawichost, f. Bóbr - Żagań. Source: the authors' own results
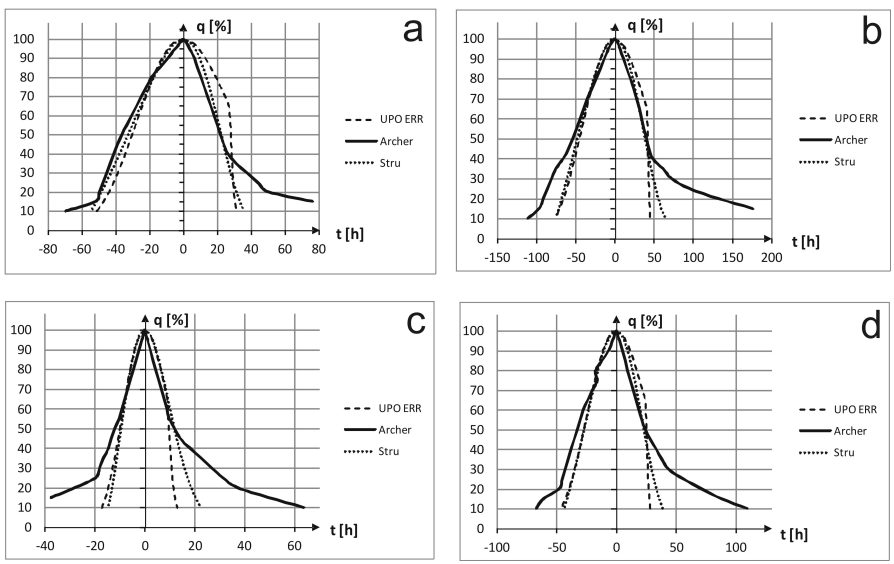

Fig. 3. Examples of parametric design hydrographs determined by the UPO ERR Gamma function (UPO ERR) and the Strupczewski function (Stru) and a nonparametric hydrograph determined by the Archer method (Archer et al 2000) for the 4 largest flood waves (gauged cross-sections) where the skewness coefficient $s \geq 0.5$ : a. San - Przemyśl, b. San - Rzuchów, c. Raba - Stróża, d. Dunajec - Żabno. Source: the authors' own results 
Table 2. Compilation of relative error values calculated from Eq. (11) for percentiles $p=75 \%$ and $p=50 \%$ for the UPO ERR Gama function (UPO) and for the Strupczewski formula (Stru) in the upper Vistula catchments (Nos. 1-15) and the middle Odra catchments (Nos.16-30)

\begin{tabular}{|c|l|c|c|c|c|}
\hline \multirow{2}{*}{ No. } & \multirow{2}{*}{ River gauging station } & \multicolumn{2}{|c|}{$\mathrm{RE}_{75}$} & \multicolumn{2}{c|}{$\mathrm{RE}_{50}$} \\
\cline { 3 - 6 } & & UPO & Stru & UPO & Stru \\
\hline 1 & Żabniczanka - Żabnica & 0.16 & 0.15 & 0.01 & 0.08 \\
\hline 2 & Grajcarek - Szczawnica & 0.26 & 0.22 & 0.08 & 0.16 \\
\hline 3 & Wieprzówka - Rudze & 0.22 & 0.28 & 0.07 & 0.09 \\
\hline 4 & Uszwica - Borzęcin & 0.12 & 0.13 & 0.04 & 0.09 \\
\hline 5 & Wisła - Skoczów & 0.07 & 0.14 & 0.01 & 0.07 \\
\hline 6 & Koprzywianka - Koprzywnica & 0.13 & 0.13 & 0.05 & 0.10 \\
\hline 7 & Raba - Stróża & 0.21 & 0.23 & 0.10 & 0.11 \\
\hline 8 & Biała - Koszyce Wielkie & 0.15 & 0.14 & 0.07 & 0.12 \\
\hline 9 & Przemsza - Jeleń & 0.13 & 0.18 & 0.06 & 0.11 \\
\hline 10 & Poprad - Stary Sącz & 0.19 & 0.14 & 0.07 & 0.12 \\
\hline 11 & Nida - Brzegi & 0.06 & 0.20 & 0.00 & 0.06 \\
\hline 12 & San - Przemyśl & 0.19 & 0.04 & 0.05 & 0.04 \\
\hline 13 & Dunajec - Żabno & 0.35 & 0.17 & 0.08 & 0.13 \\
\hline 14 & San - Rzuchów & 0.18 & 0.05 & 0.07 & 0.08 \\
\hline 15 & Wisła - Zawichost & 0.14 & 0.46 & 0.05 & 0.16 \\
\hline 16 & Nysa Kłodzka - Międzylesie & 0.43 & 0.28 & 0.01 & 0.16 \\
\hline 17 & Bystrzyca - Jugowice & 0.46 & 0.26 & 0.02 & 0.06 \\
\hline 18 & Bóbr - Kamienna Góra & 0.14 & 0.08 & 0.05 & 0.05 \\
\hline 19 & Czarna Woda - Gniechowice & 0.06 & 0.09 & 0.03 & 0.08 \\
\hline 20 & Biała Głuchołaska - Głuchołazy & 0.23 & 0.40 & 0.00 & 0.09 \\
\hline 21 & Piława - Mościsko & 0.07 & 0.42 & 0.02 & 0.04 \\
\hline 22 & Strzegomka - Łażany & 0.02 & 0.03 & 0.04 & 0.04 \\
\hline 23 & Bóbr - Wojanów & 0.27 & 0.32 & 0.06 & 0.13 \\
\hline 24 & Nysa Kłodzka - Kłodzko & 0.12 & 0.25 & 0.13 & 0.12 \\
\hline 25 & Bóbr - Dąbrowa Bolesławiecka & 0.05 & 0.43 & 0.02 & 0.17 \\
\hline 26 & Bystrzyca - Jarnołtów & 0.02 & 0.18 & 0.02 & 0.06 \\
\hline 27 & Nysa Kłodzka - Bardo & 0.30 & 0.30 & 0.06 & 0.15 \\
\hline 28 & Bóbr - Szprotawa & 0.01 & 0.39 & 0.03 & 0.14 \\
\hline 29 & Bóbr - Żagań & 0.02 & 0.30 & 0.00 & 0.12 \\
\hline 30 & Odra - Cigacice & 0.21 & 0.06 & 0.14 \\
\hline Source: the aun' owown study & & & \\
\hline
\end{tabular}

Source: the authors' own study

according to the formula Eq. (12). In the case of the Jelen cross-section on the Przemsza river, due to the lack of percentile $p=25 \%$, percentile $p=30 \%$ was used in the nonparametric hydrograph; for the other cross-sections, percentile $p=25 \%$ was used. The values of relative error for the volume of hydrographs above three basic percentiles $p=75 \%, p=50 \%$ and $p=25 \%$ (in the Jeleń cross-section on the Przemsza river $p=30 \%$ ) are presented in Table 4 . 
Table 3. Mean relative error for percentiles above $p=75 \%, p=50 \%$, and $p=25 \%$ for the UPO ERR Gamma and Strupczewski methods regarding a non-parametric hydrograph determined by the Archer method

\begin{tabular}{|c|c|c|c|c|c|c|c|}
\hline \multirow{2}{*}{ No. } & \multirow{2}{*}{ River gauging station } & \multicolumn{2}{|c|}{$\mathrm{MRE}_{75}$} & \multicolumn{2}{|c|}{$\mathrm{MRE}_{50}$} & \multicolumn{2}{|c|}{$\mathrm{MRE}_{25}$} \\
\hline & & UPO & Stru & UPO & Stru & UPO & Stru \\
\hline 1 & Żabniczanka - Żabnica & 0.69 & 0.67 & 0.41 & 0.41 & 0.29 & 0.34 \\
\hline 2 & Grajcarek - Szczawnica & 1.24 & 1.18 & 0.71 & 0.69 & 0.53 & 0.55 \\
\hline 3 & Wieprzówka - Rudze & 0.71 & 0.79 & 0.42 & 0.47 & 0.33 & 0.38 \\
\hline 4 & Uszwica - Borzęcin & 0.30 & 0.29 & 0.18 & 0.18 & 0.13 & 0.17 \\
\hline 5 & Wisła - Skoczów & 0.28 & 0.34 & 0.17 & 0.21 & 0.15 & 0.21 \\
\hline 6 & Koprzywianka - Koprzywnica & 0.82 & 0.83 & 0.46 & 0.48 & 0.38 & 0.42 \\
\hline 7 & Raba - Stróża & 1.07 & 1.11 & 0.61 & 0.64 & 0.50 & 0.54 \\
\hline 8 & Biała - Koszyce Wielkie & 1.01 & 0.93 & 0.57 & 0.54 & 0.57 & 0.47 \\
\hline 9 & Przemsza - Jeleń & 0.90 & 0.98 & 0.50 & 0.57 & $0.39^{*)}$ & $0.45^{*)}$ \\
\hline 10 & Poprad - Stary Sącz & 1.05 & 0.96 & 0.60 & 0.55 & 0.45 & 0.44 \\
\hline 11 & Nida - Brzegi & 0.36 & 0.49 & 0.20 & 0.30 & 0.15 & 0.24 \\
\hline 12 & San - Przemyśl & 0.68 & 0.46 & 0.41 & 0.26 & 0.33 & 0.22 \\
\hline 13 & Dunajec - Żabno & 1.14 & 0.86 & 0.67 & 0.51 & 0.54 & 0.42 \\
\hline 14 & San - Rzuchów & 0.55 & 0.40 & 0.33 & 0.24 & 0.31 & 0.23 \\
\hline 15 & Wisła - Zawichost & 0.54 & 0.90 & 0.33 & 0.59 & 0.29 & 0.44 \\
\hline 16 & Nysa Kłodzka - Międzylesie & 1.26 & 0.99 & 0.75 & 0.58 & 0.56 & 0.50 \\
\hline 17 & Bystrzyca - Jugowice & 1.02 & 0.75 & 0.64 & 0.45 & 0.53 & 0.39 \\
\hline 18 & Bóbr - Kamienna Góra & 0.79 & 0.70 & 0.45 & 0.40 & 0.38 & 0.35 \\
\hline 19 & Czarna Woda - Gniechowice & 0.12 & 0.13 & 0.10 & 0.11 & 0.08 & 0.13 \\
\hline 20 & Biała Głuchołaska - Głuchołazy & 0.21 & 0.34 & 0.20 & 0.29 & 0.17 & 0.27 \\
\hline 21 & Piława - Mościsko & 0.24 & 0.59 & 0.15 & 0.37 & 0.13 & 0.26 \\
\hline 22 & Strzegomka - Łażany & 0.07 & 0.12 & 0.06 & 0.08 & 0.07 & 0.08 \\
\hline 23 & Bóbr - Wojanów & 0.15 & 0.18 & 0.12 & 0.15 & 0.11 & 0.18 \\
\hline 24 & Nysa Kłodzka - Kłodzko & 1.25 & 1.09 & 0.72 & 0.63 & 0.53 & 0.50 \\
\hline 25 & Bóbr - Dąbrowa Bolesławiecka & 0.55 & 1.04 & 0.32 & 0.65 & 0.24 & 0.54 \\
\hline 26 & Bystrzyca - Jarnołtów & 0.41 & 0.46 & 0.23 & 0.34 & 0.19 & 0.26 \\
\hline 27 & Nysa Kłodzka - Bardo & 1.46 & 1.39 & 0.82 & 0.80 & 0.59 & 0.61 \\
\hline 28 & Bóbr - Szprotawa & 0.53 & 1.02 & 0.33 & 0.62 & 0.36 & 0.45 \\
\hline 29 & Bóbr - Żagań & 0.42 & 0.73 & 0.25 & 0.47 & 0.25 & 0.35 \\
\hline 30 & Odra-Cigacice & 0.40 & 0.55 & 0.25 & 0.33 & 0.23 & 0.34 \\
\hline
\end{tabular}

*) percentile $p=30 \%$;

Source: the authors' own study

Figure 4 shows the position of gravity centers $r_{0}$ for the parametric design hydrographs above percentiles $p=25 \%, p=50 \%$ and $p=75 \%$ in relation to the gravity centers for the non-parametric hydrographs determined by the Archer method.

In addition, Table 5 shows the values of the skewness coefficient $s$ for the flow descriptor W50\% for the non-parametric hydrograph determined by the Archer method 
Table 4. Relative error of the volume of a parametric hydrograph developed by the UPO ERR Gamma method and the Strupczewski method for the hydrograph above percentiles $p=75 \%$, $p=50 \%$ and $p=25 \%$ relative to the volume of the Archer nonparametric hydrograph

\begin{tabular}{|c|c|c|c|c|c|c|c|}
\hline \multirow{2}{*}{ No. } & \multirow{2}{*}{ River gauging station } & \multicolumn{2}{|c|}{$\mathrm{ErV}_{75}$} & \multicolumn{2}{|c|}{$\mathrm{ErV}_{50}$} & \multicolumn{2}{|c|}{$\mathrm{ErV}_{25}$} \\
\hline & & UPO & Stru & UPO & Stru & UPO & Stru \\
\hline 1 & Żabniczanka - Żabnica & 0.36 & 0.36 & 0.15 & 0.11 & 0.05 & -0.04 \\
\hline 2 & Grajcarek - Szczawnica & 0.67 & 0.66 & 0.15 & 0.12 & 0.00 & -0.09 \\
\hline 3 & Wieprzówka - Rudze & 0.49 & 0.58 & 0.14 & 0.18 & -0.01 & -0.03 \\
\hline 4 & Uszwica - Borzęcin & 0.26 & 0.26 & 0.09 & 0.07 & 0.03 & -0.04 \\
\hline 5 & Wisła - Skoczów & 0.21 & 0.29 & 0.08 & 0.10 & -0.03 & -0.08 \\
\hline 6 & Koprzywianka - Kol & 0.39 & 0.40 & 0.10 & 0.09 & -0.07 & -0.13 \\
\hline 7 & Raba - Stróża & 0.55 & 0.60 & 0.16 & 0.18 & -0.10 & -0.12 \\
\hline 8 & Biała - Koszyce Wielkie & 0.49 & 0.46 & 0.12 & 0.09 & -0.09 & -0.16 \\
\hline 9 & Przemsza - Jeleń & 0.42 & 0.49 & 0.10 & 0.12 & $0.04^{*)}$ & $-0.01^{*)}$ \\
\hline 10 & Poprad - Stary Sącz & 0.53 & 0.51 & 0.15 & 0.11 & 0.00 & -0.05 \\
\hline 11 & Nida - Brzegi & 0.25 & 0.38 & 0.05 & 0.11 & 0.05 & -0.01 \\
\hline 12 & San - Przemyśl & 0.40 & 0.21 & 0.16 & 0.05 & -0.01 & -0.03 \\
\hline 13 & Dunajec - Żabno & 0.56 & 0.40 & 0.20 & 0.08 & -0.05 & -0.09 \\
\hline 14 & San - Rzuchów & 0.40 & 0.28 & 0.14 & 0.05 & -0.08 & -0.09 \\
\hline 15 & Wisła - Zawichost & 0.36 & 0.72 & 0.14 & 0.30 & 0.16 & 0.03 \\
\hline 16 & Nysa Kłodzka - Międz & 0.83 & 0.64 & 0.30 & 0.15 & 0.04 & -0.13 \\
\hline 17 & Bystrzyca - Jugowice & 0.70 & 0.49 & 0.32 & 0.18 & -0.05 & -0.10 \\
\hline 18 & Bóbr - Kamienna Góra & 0.46 & 0.40 & 0.13 & 0.09 & -0.07 & -0.09 \\
\hline 19 & Czarna Woda-Gniechowice & 0.05 & 0.07 & 0.04 & 0.04 & -0.01 & -0.06 \\
\hline 20 & Biała Głuchołaska - Głuchołazy & 0.20 & 0.34 & 0.19 & 0.24 & 0.05 & -0.05 \\
\hline 21 & Piława-Mościsko & 0.21 & 0.35 & 0.02 & 0.07 & 0.06 & 0.05 \\
\hline 22 & Strzegomka - Łażany & -0.05 & -0.11 & 0.02 & -0.02 & -0.02 & -0.03 \\
\hline 23 & Bóbr - Wojanów & 0.12 & 0.15 & 0.08 & 0.09 & -0.02 & -0.10 \\
\hline 24 & Nysa Kłodzka - Kłodzko & 0.70 & 0.61 & 0.21 & 0.18 & 0.02 & -0.04 \\
\hline 25 & Bóbr - Dąbrowa Bolesławiecka & 0.46 & 0.95 & 0.07 & 0.24 & 0.04 & -0.10 \\
\hline 26 & Bystrzyca - Jarnołtów & 0.20 & 0.36 & 0.06 & 0.12 & 0.07 & 0.00 \\
\hline 27 & Nysa Kłodzka - Bardo & 0.79 & 0.77 & 0.18 & 0.15 & 0.05 & -0.06 \\
\hline 28 & Bóbr - Szprotawa & 0.29 & 0.74 & -0.02 & 0.10 & 0.21 & 0.04 \\
\hline 29 & Bóbr - Żagań & 0.27 & 0.58 & 0.08 & 0.21 & 0.15 & 0.03 \\
\hline 30 & Odra-Cigacice & 0.25 & 0.40 & 0.03 & 0.09 & -0.12 & -0.19 \\
\hline
\end{tabular}

*) percentile $p=30 \%$;

Source: the authors' own study

and for the parametric hydrographs determined by the UPO ERR Gamma method and the Strupczewski method.

It can be noticed that the flood shape parameters in these two methods have different values. Moreover, the ascent time parameter in the Strupczewski method is nearly half the value determined by the UPO ERR Gamma method (Fig. 5a). This 
Table 5. Skewness coefficients $s$ and relative errors (RE) for the parametric hydrographs developed by the UPO ERR Gamma (UPO ERR) method and the Strupczewski method (Stru) and the non-parametric hydrograph developed by the Archer method. The relative error for parametric hydrographs was determined in relation to the non-parametric hydrograph

\begin{tabular}{|c|c|c|c|c|c|c|}
\hline \multirow{2}{*}{ No. } & \multirow{2}{*}{ River gauging station } & \multicolumn{3}{|c|}{ coefficient $s$ was computed for W50 } & \multicolumn{2}{|l|}{$\mathrm{RE}$} \\
\hline & & Archer[-] & UPO ERR[-] & Stru $[-]$ & UPO ERR[\%] & Stru[\%] \\
\hline 1 & Żabniczanka - Żabnica & 0.4 & 0.41 & 0.4 & 2.5 & 0.0 \\
\hline 2 & Grajcarek - Szczawnica & 0.48 & 0.41 & 0.47 & 14.6 & 2.1 \\
\hline 3 & Wieprzówka - Rudze & 0.43 & 0.39 & 0.4 & 9.3 & 7.0 \\
\hline 4 & Uszwica - Borzęcin & 0.42 & 0.4 & 0.38 & 4.8 & 9.5 \\
\hline 5 & Wisła - Skoczów & 0.39 & 0.38 & 0.37 & 2.6 & 5.1 \\
\hline 6 & $\begin{array}{l}\text { Koprzywianka - } \\
\text { Koprzywnica }\end{array}$ & 0.45 & 0.44 & 0.45 & 2.2 & 0.0 \\
\hline 7 & Raba - Stróża & 0.5 & 0.47 & 0.46 & 6.0 & 8.0 \\
\hline 8 & Biała - Koszyce Wielkie & 0.47 & 0.46 & 0.47 & 2.1 & 0.0 \\
\hline 9 & Przemsza - Jeleń & 0.4 & 0.36 & 0.35 & 10.0 & 12.5 \\
\hline 10 & Poprad - Stary Sącz & 0.51 & 0.47 & 0.47 & 7.8 & 7.8 \\
\hline 11 & Nida - Brzegi & 0.3 & 0.28 & 0.27 & 6.7 & 10.0 \\
\hline 12 & San - Przemyśl & 0.62 & 0.52 & 0.59 & 16.1 & 4.8 \\
\hline 13 & Dunajec - Żabno & 0.58 & 0.57 & 0.55 & 1.7 & 5.2 \\
\hline 14 & San - Rzuchów & 0.57 & 0.51 & 0.55 & 10.5 & 3.5 \\
\hline 15 & Wisła-Zawichost & 0.29 & 0.25 & 0.25 & 13.8 & 13.8 \\
\hline 16 & $\begin{array}{l}\text { Nysa Kłodzka - } \\
\text { Międzylesie }\end{array}$ & 0.45 & 0.45 & 0.5 & 0.0 & 11.1 \\
\hline \multirow[t]{2}{*}{17} & Bystrzyca - Jugowice & 0.53 & 0.5 & 0.5 & 5.7 & 5.7 \\
\hline & Bóbr - Kamienna Góra & 0.51 & 0.47 & 0.55 & 7.8 & -7.8 \\
\hline 19 & $\begin{array}{l}\text { Czarna Woda - } \\
\text { Gniechowice }\end{array}$ & 0.39 & 0.38 & 0.37 & 2.6 & 5.1 \\
\hline 20 & $\begin{array}{l}\text { Biała Głuchołaska - } \\
\text { Głuchołazy }\end{array}$ & 0.29 & 0.33 & 0.33 & 13.8 & 13.8 \\
\hline 21 & Piława-Mościsko & 0.27 & 0.26 & 0.27 & 3.7 & 0.0 \\
\hline 22 & Strzegomka - Łażany & 0.28 & 0.31 & 0.3 & 10.7 & 7.1 \\
\hline 23 & Bóbr - Wojanów & 0.4 & 0.38 & 0.35 & 5.0 & 12.5 \\
\hline 24 & Nysa Kłodzka - Kłodzko & 0.47 & 0.48 & 0.5 & 2.1 & 6.4 \\
\hline 25 & $\begin{array}{l}\text { Bóbr - Dąbrowa } \\
\text { Bolesławiecka }\end{array}$ & 0.25 & 0.23 & 0.27 & 8.0 & 8.0 \\
\hline 26 & Bystrzyca - Jarnołtów & 0.24 & 0.24 & 0.26 & 0.0 & 8.3 \\
\hline 27 & Nysa Kłodzka - Bardo & 0.42 & 0.4 & 0.38 & 4.8 & 9.5 \\
\hline 28 & Bóbr - Szprotawa & 0.19 & 0.2 & 0.21 & 5.3 & 10.5 \\
\hline 29 & Bóbr-Żagań & 0.25 & 0.24 & 0.25 & 4.0 & 0.0 \\
\hline \multirow[t]{2}{*}{30} & Odra-Cigacice & 0.37 & 0.32 & 0.35 & 13.5 & 5.4 \\
\hline & Average error RE & & & & 6.6 & 6.2 \\
\hline
\end{tabular}

Source: the authors' own results 

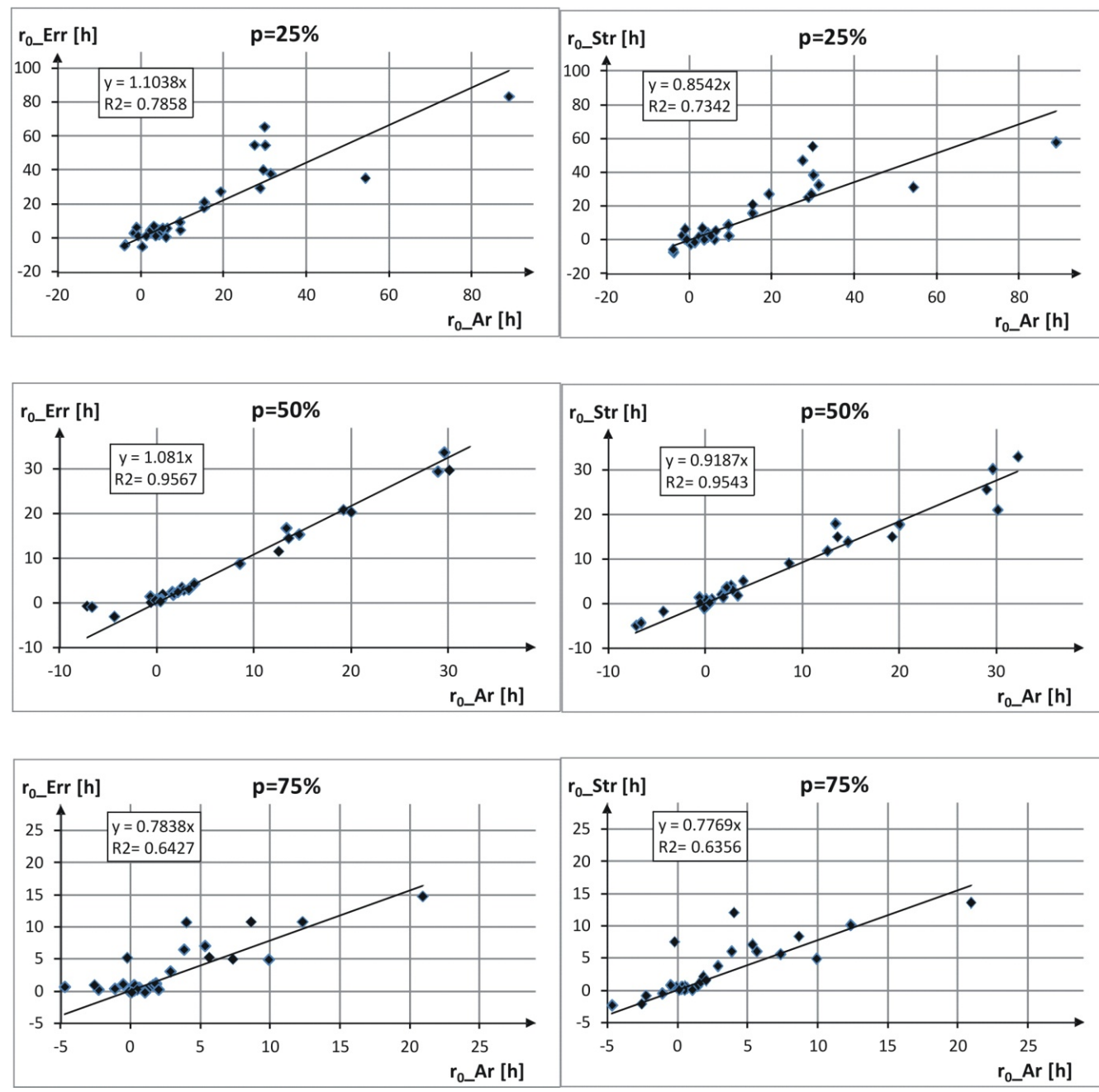

Fig. 4. Relations between the position of the gravity centers for the parametric hydrographs $r_{0}\left(r_{0}\right.$ Err - determined by the UPO ERR Gamma method, $r_{0}$ Str - determined by the Strupczewski method) and the position of the gravity centers for the non-parametric hydrographs determined by the Archer method $-\mathrm{r}_{0} \_$Ar). Source: the authors' own study

means, that parametric hydrographs on the rising side in the Strupczewski method are more slender, which may have an impact on design calculations because of the higher growth rate of flow. Depending on the calculated parameters for both methods of description the parametric hydrographs are presented in Figs. 5a, 5b and 5c.

\section{Conclusions}

On the basis of the above analyses it may be stated that for both catchments the upper parts of the hydrographs show a poor match to the nonparametric hydrograph assumed 

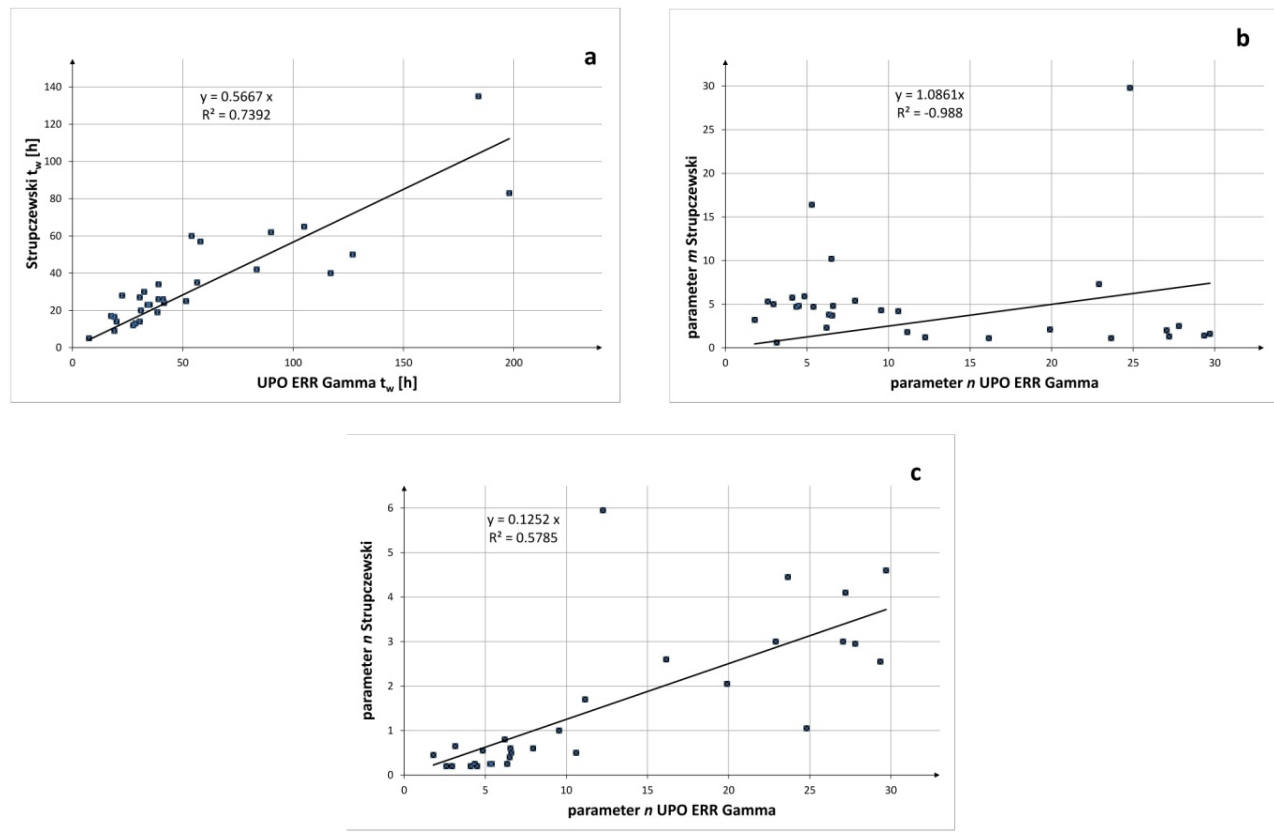

Fig. 5. Parameters calculated for parametric hydrographs in gauged cross-section in the upper basin of the Vistula river and the middle basin of the Odra river by the UPO ERR Gamma method and the Strupczewski method: a. ascent time $t_{w}(h), \mathrm{b}$. hydrograph shape parameter $m$ in the Strupczewski method and the shape parameter $n$ in the UPO ERR Gamma method, c. hydrograph shape parameter $n$ in the Strupczewski method and the shape parameter $n$ in the UPO ERR Gamma method. Source: the authors' own results

as the model. One of the reasons are the available data. The data were collected in a traditional way, from the staff gauge readings, i.e. every few hours. Only in few cases hydrographs from an automatic system were available. Due to the principles of nonparametric hydrograph construction the data did not have any significant effect on the ultimate course of the hydrograph. Evaluation of the upper part of the hydrograph should be based on comparison of the two methods used to determine parametric hydrographs. Regarding the numbers, more hydrographs with smaller errors were obtained by the UPO ERR Gamma method than by the Strupczewski method.

The errors in the upper part of the parametric hydrograph affected the overall assessment by $\mathrm{MRE}_{p}$. Therefore, the results of this part of the study were not taken into consideration. Far better results were obtained from volume assessments, in which hydrographs obtained by both methods were satisfactory. The volume is the basic parameter used in the design process.

The values of the determined center of gravity indicate that the hydrographs determined by the Strupczewski method are shifted towards the ascending part (above the percentiles $p=25 \%$ and $p=50 \%$ ), whereas the hydrographs defined by the UPO ERR Gamma method towards the descending part. The shift of the gravity center to- 
wards the ascending part points to the greater mass of hydrographs in that part; in the design process such a situation is more advantageous than the opposite one. It should be noted that this shift does not apply to the skewness coefficient $s$, and therefore it is not a good indicator of the rating.

Evaluation of a parametric hydrograph on the basis of the position of the gravity center provided a conclusive proof of the superiority of the Strupczewski method over the UPO ERR Gamma method. This type of indicator will be used during further research.

Visual judgment is not without significance, and in the authors' opinion better results were achieved for nonparametric hydrographs similar in the shape of the receding part to hydrographs designed by the UPO ERR Gamma method. When the hydrographs show a typical course in their receding part, the Strupczewki method is better. This method also gives a better match when the skewness coefficient $s>$ 0.5 ; there were several such cases in the analyzed cross sections. The advantage of a single-function description of a parametric hydrograph is obvious in this situation.

The Strupczewski method has one main advantage: it describes the whole hydrograph using a single function and, like the UPO ERR Gamma method, it is composed of three parameters. Parametric hydrographs determined on the basis of two width-hydrograph descriptors W75 and W50 and the skewness coefficient $s$ are accurate enough for design purposes. Smaller $\mathrm{RE}_{p}$ and $\mathrm{ErV}_{p}$ errors are observed when negative shape parameters are used. For example, for the Szprotawa cross section on the Bóbr river, $\mathrm{RE}_{75}=0.11$ and $\mathrm{ER}_{50}=0.06$, whereas for the positive parameters $\mathrm{RE}_{75}=0.39, \mathrm{ER}_{50}=0.14$. The assumption that shape parameters significantly worsen the quality of results is necessary because the method should meet the applicability criteria in ungauged sections (for which the shape parameters $m$ and $n$ and the rising time $t_{w}$ are known). It may be assumed that the principle of positive shape coefficients is obligatory only for ungauged cross sections, whereas negative parameters may be additionally considered for gauged cross sections. This assumption results in the fact that most design hydrographs determined by the Strupczewski method have smaller $\mathrm{RE}_{p}$ and $\mathrm{ErV}_{p}$ errors than those determined by the UPO ERR Gamma method.

The method's sensitivity to non-standard cases of a nonparametric hydrograph course or the inflection point in the UPO ERR Gamma method is also important. If the inflection point is too close to the width-hydrograph descriptor W50, the Strupczewski method is less sensitive to such disturbances.

The shorter time in the rising part of parametric design hydrographs in the Strupczewski method has an impact on the rules of design calculations. It may be regarded as a positive feature of the solution, but also as a less realistic description of the flood hydrograph phenomenon.

In conclusion, the authors suggest that the Strupczewski method should be used to determine parametric design hydrographs because of the better mapping of design hydrographs in uncontrolled sections. 


\section{References}

Apel H., Thieken A. H., Merz B., Blöschl G. (2006) A Probabilistic Modelling System For Assessing Flood Risks, Natural Hazards, 38, 295-308.

Archer D., Foster M., Faulkner D., Mawdsley H. (2000) The Synthesis of Design Flood Hydrographs, Proc. Flooding: Risks And Reactions, CIWEM/ICE Conference, London, 45-57.

Baptista M., Michel C. (1990) Influence Des Caracteristiques Hydrauliques Des Bies Sur La Propagation Des Pointes De Crue, La Houille Blanche, 2, 141-148.

Ciepielowski A. (1987) Statistical Methods of Determining Typical Winter and Summer Hydrographs for Ungauged Watersheds, International Symposium on Hood Frequency and Risk Analyses, Department of Civil Engineering, Louisiana State University, Baton Rouge, 117-124.

Ciepielowski A. (2001) Relationships Between Selected Elements of the Flood Hydrographs in Rivers, Journal of Water and Land Development, (5), 89-105.

Criss R. E., Winston W. E. (2008) Discharge Predictions of a Rainfall-Driven Theoretical Hydrograph Compared to Common Models and Observed Data, Water Resources Research, 44, W10407, Doi:10.1029/2007WR006415

Elshorbagy A., Simonovic S. P., Panu U. S. (2000) Performance Evaluation of Artificial Neural Networks for Runoff Prediction, Journal of Hydrologic Engineering, 5, 424-427.

Gądek W., Środula A. (2014), The Evaluation of the Design Flood Hydrographs Determined with the Hydroproject Method in the Gauged Catchments, Infrastruktura i Ekologia Terenów Wiejskich, $\mathrm{Nr}$ 2014/IV (3), 1355-1366.

Gądek W., Bodziony M. (2015) The Hydrological Model and Formula for Determining the Hypothetical Flood Wave Volume in Non-Gauged Basin, Meteorology, Hydrology and Water Management, 3 (1), 3-10.

Gądek W., Tokarczyk T. (2015) Determining Hypothetical Floods in the Odra Basin by Means of the Cracow Method and by Volume Formula, Infrastructure and Ecology of Rural Areas, IV/4, 1507-1519.

Gądek W., Tokarczyk T., Środula A. (2016) Estimation of Parametric Flood Hydrograph Determined by Means of Strupczewski Method in the Vistula and Odra Catchments, Journal of Water and Land Development, 31 (X-XII), 43-51.

Gądek W., Baziak B., Tokarczyk T. (2017) Nonparametric Design Hydrograph in the Gauged Cross Sections of the Vistula and Odra Catchment, Meteorology Hydrology and Water Management, 51 , 53-61.

Hayashi T., Nagamine Y., Nishida A. (1986) A Vibration Model to Describe the Lactation Curve of a Dairy Cow, Japanese Journal of Zootechnical Science, 57, 471-478.

Hattermann F. F., Kundzewicz Z. W. (Ed.) (2010) Water Framework Directive: Model Supported Implementation. A Water Manager's Guide, IWA Publishing, London.

Krišèiukaitiene I., Baležentis T., Galnaityté A., Namiotko V. (2015) A Methodology for Flood Risk Appraisal in Lithuania, Journal of Water and Land Development, (25), 13-22.

McEnroe B. M. (1992) Sizing Stormwater Detention Reservoirs to Reduce Peak Flow, Hydraulic Engineering: Saving a Threatened Resource - in Search of Solutions, Conference Proceeding Paper, Reston. VA. ASCE., 719-724.

Mioduszewski W. (2012) Small Water Reservoirs - Their Function and Construction, Journal of Water and Land Development, (17), 45-52.

Mioduszewski W. (2014) Small (Natural) Water Retention in Rural Areas, Journal of Water and Land Development, (20), 19-29.

O’Connor K., Goswami M., Faulkner D. (2014) Flood Studies Update. Technical Research Report, Volume III. Hydrograph Analysis, 186 pp. 
Ozga-Zielińska M., Gądek W., Książyński K., Nachlik E., Szczepanek R. (2002) Mathematical Model of Rainfall-Runoff Transformation - WISTOO, Mathematical Models of Large Watershed Hydrology, Ed. Singh V. P., Frevert D. K., Water Resources Publications, LLC, Littleton, Colorado, 811-860.

Pietrusiewicz I., Cupak A., Wałęga A., Michalec B. (2014) The Use of NRCS Synthetic Unit Hydrograph and Wackermann Conceptual Model in the Simulation of a Flood Wave in an Uncontrolled Catchment, Journal of Water and Land Development, (23), 53-59.

Strupczewski W. (1964)Equation of Flood Crest, Wiadomości Stużby Hydrologicznej i Meteorologicznej, 2 (57), 35-58.

Vrijling J. K., Van Hengel W., Houben R. J. (1998) Acceptable Risk as a Basis for Design, Reliability Engineering and System Safety, 59, 141-150.

Tokarczyk T., Szalińska W. (2013) The Operational Drought Hazard Assessment Scheme - Performance and Preliminary Results, Archives of Environmental Protection, 39 (3), 61-77,

Wałęga A. (2013) Application of HEC-HMS Programme for the Reconstruction of a Flood Event in an Uncontrolled Basin, Journal of Water and Land Development, (18), 13-20.

WMO (2008) Urban Flood Risk Management. A Tool for Integrated Flood Management.

Zevenbergen C., Cashman A., Evelpidou N., Pasche E., Garvin S., Ashley R. (2011) Urban Flood Management, CRC Press London. 